\title{
Effect of Integrated Nutrient Management on Growth Attributes and Soil Nutrient Status of Tomato under Naturally Ventilated Polyhouse
}

\author{
K. S. Rajawat ${ }^{1 *}$, K. D. Ameta ${ }^{1}$, R. A. Kaushik ${ }^{1}$, R. B. Dubey ${ }^{2}$, \\ H. K. Jain ${ }^{3}$, Devendara Jain ${ }^{4}$ and M. K. Kaushik ${ }^{5}$
}

${ }^{1}$ Department of Horticulture, ${ }^{2}$ Department of GPB, ${ }^{3}$ Department of Statistics, ${ }^{4}$ Department of $M B B T,{ }^{5}$ Department of Agronomy Rajasthan College of Agriculture, MPUAT, Udaipur, India

*Corresponding author

Keywords

Tomato, Growth, Organic manures, Inorganic fertilizers and polyhouse

Article Info

Accepted:

07 September 2019

Available Online:

10 October 2019
An experiment was carried out at Hi-tech Unit, Department of Horticulture, Rajasthan College of Agriculture, MPUAT, Udaipur during two consecutive years 2017 and 2018, to assess the effect of various organic manures, chemical fertilizers and biofertilizers of growth and its attributes of tomato under naturally ventilated polyhouse. The experiment was laid out in completely randomized design with eight treatment combinations replicated four times. Treatment $\mathrm{T}_{8}(75 \%$ organic management $+25 \%$ inorganic fertilizers) recorded maximum plant height at 90 DAT (183.40 $\mathrm{cm})$, plant height at final stage of harvesting $(245.18 \mathrm{~cm})$, whereas maximum leaf area $\left(89.24 \mathrm{~cm}^{2}\right)$ and stem diameter $(1.46 \mathrm{~cm})$ were recorded with treatment $\mathrm{T}_{2}(100 \% \mathrm{RDF}+$ biofertilizers $)$. Maximum branches per plant (8.69), maximum clusters per plant (8.08) and maximum fruits per cluster (6.60) were recorded with treatment $\mathrm{T}_{3}(100 \%$ vermicompost + biofertilizers). Maximum NPK nutrient uptake was observed with combined applications of organic manures and inorganic fertilizers as compared to chemical fertilizers alone.

\section{Introduction}

Tomato (Solanum lycopersicon L.) is one of the most important vegetable crop in the world. It belongs to the family solanaceae have diploid chromosome number 24 and a self pollinated crop. Tomato is originated from Peru, Ecuador and Boliviya on the basis of availability of numerous wild and cultivated relatives exist in these area. It is cultivated in 
both temperate and tropical regions of the world. It is consumed in various ways like fresh in salads and sandwiches, cooked or processed in ketchup, sauces, juices or dried powder.

Production of vegetables under protected conditions involves protection of various stages of vegetables mainly from adverse environmental conditions such as temperature, high rainfall, hail storms, scorching sun light etc. Protected conditions for vegetable production are created locally by using different types of structures. In greenhouses, the management of soil fertility is of utmost importance for optimizing crop nutrition on both a short-term and a long-term basis to achieve sustainable crop production. It is related to the greenhouse climate and the complex interaction involving the many factors contributing to the biological, chemical and physical properties of the soil. Biological factors can be beneficial (microbial population, mycorrhizal fungi, Rhizobium bacteria) and physical properties importance for greenhouse production is soil texture and structures the soil volume that can be explored by the roots, and its water-holding capacity. Chemical factors contributing to soil fertility include nutrient status and soil organic matter, soil $\mathrm{pH}$ and cation exchange capacity.

The main components of integrated nutrients management are fertilizers, organic manures, legumes, crop residues and biofertilizers. Chemical fertilizers are considered as a compulsory component for crop production but the continuous and excess application not only reduces the profitability but also deteriorates environment quality. The use of chemical fertilizers in combinations with organic manures is helpful for improving soil health and sustaining crop production and soil fertility (Ahamd et al., 2015). Besides, fertilizers there are several sources of plant nutrients such as FYM, vermicompost, neem cake and biodynamic manure has a positive effect on crop production. Vermicompost has all characteristics to use it as the most valuable organic manure. Biofertilizers are efficient, eco-friendly, environmentally safe, cost effective, and economically viable and ecologically sound.

\section{Materials and Methods}

An experiment was carried out at Hi-tech Unit, Department of Horticulture, Rajasthan College of Agriculture, MPUAT, Udaipur during two consecutive years 2017 and 2018, to assess the effect of various organic manures, chemical fertilizers and biofertilizers of growth and its attributes of tomato under naturally ventilated polyhouse. The experiment was laid out in completely randomized design with eight treatment combinations replicated four times. The treatments involved were $\mathrm{T}_{1^{-}} 100$ per cent RDF (RDF @ 180:100:100 NPK kg/ha), T $2^{-}$ 100 per cent RDF+ biofertilizers, $\mathrm{T}_{3}-100$ per cent vermicompost @ 10 t/ha + biofertilizers $(\mathrm{PSB}+\mathrm{ZSB}+$ Azotobector @ $4 \mathrm{~kg} / \mathrm{ha}), \mathrm{T}_{4^{-}}$ 100 per cent vermicompost, $\mathrm{T}_{5^{-}} 100$ per cent Organic Management, $\mathrm{T}_{6^{-}} \quad 75 \%$ Organic Management, $\mathrm{T}_{7^{-}} 50$ per cent Organic Management +50 per cent inorganic fertilizers, $\mathrm{T}_{8^{-}} \quad 75$ per cent Organic Management +25 per cent inorganic fertilizers. The raised beds of 1 meter width having $45 \mathrm{~cm}$ above from ground level along with length of polyhouse were prepared the plot size was $7 \mathrm{~m} \mathrm{X} 1 \mathrm{~m}$ and spacing was followed $50 \mathrm{~cm} \mathrm{X} 45 \mathrm{~cm}$. Basal dose of NADEP compost, vermi-compost, and none edible cakes were calculated as per treatment and thoroughly mixed in the soil one week before transplanting (Table 1). Bio-fertilizers $(\mathrm{PSB}+\mathrm{ZSB}+$ Azotobector $) @ 4 \mathrm{~kg}$ per ha were inoculated and applied before transplanting as seedling root dip for 30 minutes. Fertigation schedule was followed and NPK was applied in liquid form along 
with irrigation water twice in a week as water soluble NPK mixture (19:19:19) and (0:52:34) along with micronutrient and calcium nitrate.

All cultural practices were followed regularly during entire crop growth period and observations were recorded on growth characters i.e., plant height, No. of branches, stem diameter, leaf area, No. of clusters per plant, No. of fruits per cluster and soil nutrient status of tomato before and after harvesting of crop under naturally ventilated polyhouse.

\section{Results and Discussion}

\section{Growth parameters}

Data from Table 2 and 3 revealed that the differences with respect to growth attributes were significant among different treatment combinations of organic manures and inorganic fertilizers at various stages of crop growth under naturally ventilated polyhouse.

During the experiment the effect of integrated nutrient management had a significant influence on plant height at 90 days and plant height at final stage of harvesting in tomato. Pooled basis results showed that the maximum plant height $(183.40 \mathrm{~cm})$ and $(245.18 \mathrm{~cm})$ at 90 days and final stage of harvesting were recorded with the application of 75 per cent organic +25 per cent inorganic fertilizers in $\mathrm{T}_{8}$ whereas minimum plant height at $(146.60$ $\mathrm{cm}$ and 205.58) at 90 days and final stage of harvesting were observed in $\mathrm{T}_{4}(100$ per cent vermicompost alone).

The increased plant height with combined application of 75 per cent organic +25 per cent inorganic fertilizers might be due to improved nutrient absorption and translocation by plants as compared to organic and inorganic nutrients alone which results more plant height than other treatment and may also due to microclimate conditions inside the polyhouse. These findings are also in agreement with the findings of Singh et al., (2015) for tomato under polyhouse condition. Laxmi et al., (2015) in tomato and Bairwa et al., (2009) in okra.

Table.1 Initial fertility status of experimental soil

\begin{tabular}{|c|c|c|c|c|}
\hline S.No. & Soil properties & Content & Method of analysis & References \\
\hline $\mathbf{1 .}$ & Organic carbon \% & 0.57 & Rapid titration method & $\begin{array}{c}\text { Walkley and } \\
\text { Black (1947) }\end{array}$ \\
\hline $\mathbf{2 .}$ & $\begin{array}{c}\text { Available nitrogen } \\
\left(\mathrm{kg} \mathrm{ha}^{-1}\right)\end{array}$ & 224 & $\begin{array}{c}\text { Alkaline } \mathrm{KMnO}_{4} \\
\text { method }\end{array}$ & $\begin{array}{c}\text { Subbiah and } \\
\text { Asija (1956) }\end{array}$ \\
\hline $\mathbf{3 .}$ & $\begin{array}{c}\text { Available phosphorus } \\
\left(\mathrm{kg} \mathrm{ha}^{-1}\right)\end{array}$ & 29 & Olsen's method & $\begin{array}{c}\text { Olsen } \text { et al. } \\
(1954)\end{array}$ \\
\hline $\mathbf{4 .}$ & $\begin{array}{c}\text { Available potassium } \\
\left(\mathrm{kg} \mathrm{ha}^{-1}\right)\end{array}$ & 297 & $\begin{array}{c}\text { Flame photometer } \\
\text { method }\end{array}$ & Richards (1968) \\
\hline $\mathbf{5 .}$ & $\mathrm{pH}$ & 7.8 & $\begin{array}{c}\text { Electronic glass } \\
\text { electrode method }\end{array}$ & Piper (1950) \\
\hline $\mathbf{6 .}$ & EC $(\mathrm{dsm})$ & 1.7 & EC meter & \\
\hline
\end{tabular}


Table.2 Effect of different integrated nutrient levels on growth and its attributes of tomato.

\begin{tabular}{|c|c|c|c|c|c|c|c|c|c|c|c|c|c|c|c|}
\hline \multirow[t]{2}{*}{ Treatments } & \multicolumn{3}{|c|}{$\begin{array}{c}\text { Plant height at } 90 \text { DAT } \\
(\mathrm{cm})\end{array}$} & \multicolumn{3}{|c|}{$\begin{array}{c}\text { Plant height at final stage of } \\
\text { harvest }(\mathrm{cm})\end{array}$} & \multicolumn{3}{|c|}{$\begin{array}{c}\text { Number of branches } \\
\text { per plant }\end{array}$} & \multicolumn{3}{|c|}{ Stem diameter $(\mathbf{c m})$} & \multicolumn{3}{|c|}{ Leaf area $\left(\mathrm{cm}^{2}\right)$} \\
\hline & 2017 & 2018 & Pooled & 2017 & 2018 & Pooled & 2017 & 2018 & Pooled & 2017 & 2018 & Pooled & 2017 & 2018 & Pooled \\
\hline $\mathbf{T}_{1}$ & 160.60 & 158.00 & 159.30 & 220.35 & 223.05 & 221.70 & .85 & 7.41 & 7.63 & & & & 79.37 & & 78.62 \\
\hline $\mathbf{T}_{2}$ & 179.95 & 182.20 & 181.08 & 38.20 & 242.30 & 240.25 & 7.55 & 7.67 & 7.6 & 1.4 & 1.50 & 1.46 & 87.93 & 90.55 & 89.24 \\
\hline $\mathbf{T}_{3}$ & 49.90 & 151.40 & 150.65 & 11.90 & 217.05 & & & 8.82 & & 1.2 & & 1.2 & 76.27 & & 77.27 \\
\hline $\mathbf{T}_{4}$ & 45.20 & 148.00 & 146.60 & 15 & & & 7.40 & 7.06 & 7 & 1.45 & & 1.44 & 73.30 & & 73.80 \\
\hline $\mathbf{T}_{5}$ & 162.45 & 163.85 & 163.15 & 90 & 21 & 73 & 6.95 & 7.77 & 7 & 1.3 & 1 & 1.2 & 73.48 & 62 & 74.55 \\
\hline $\mathbf{T}_{6}$ & 153.90 & & & & & & & & & & & & 71.63 & & 73.02 \\
\hline $\mathbf{T}_{7}$ & 181.80 & 182.80 & 182.30 & 240.80 & 244.55 & 242.68 & 6.95 & 7.23 & 7.09 & 1.21 & 1.21 & 1.21 & 81.86 & 84.23 & 83.05 \\
\hline $\mathbf{T}_{8}$ & 182.40 & 184.40 & 183.40 & 242.05 & 248.30 & 245.18 & 6.20 & 6.49 & 6.34 & 1.10 & 1.17 & 1.14 & 83.24 & 88.23 & 85.74 \\
\hline SEm \pm & 2.62 & 2.39 & 1.91 & 5.06 & 4.80 & 3.72 & 0.08 & 0.09 & 0.06 & 0.03 & 0.04 & 0.03 & 2.42 & 2.55 & 1.84 \\
\hline CD $5 \%$ & 7.66 & 6.99 & 5.43 & 14.79 & 14.01 & 10.58 & 0.23 & 0.28 & 0.19 & 0.10 & 0.13 & 0.09 & 7.06 & 7.47 & 5.24 \\
\hline
\end{tabular}

Table.3 Effect of different integrated nutrient levels on growth attributes and soil nutrient status of tomato.

\begin{tabular}{|c|c|c|c|c|c|c|c|c|c|c|c|c|c|c|c|}
\hline \multirow[t]{2}{*}{ Treatments } & \multicolumn{3}{|c|}{$\begin{array}{c}\text { Number of clusters } \\
\text { per plant }\end{array}$} & \multicolumn{3}{|c|}{$\begin{array}{c}\text { Number of fruits per } \\
\text { cluster }\end{array}$} & \multicolumn{3}{|c|}{$\begin{array}{l}\text { Available nitrogen in soil } \\
\text { (kg/ha) }\end{array}$} & \multicolumn{3}{|c|}{$\begin{array}{c}\text { Available phosphorus in } \\
\text { (soil kg/ha) }\end{array}$} & \multicolumn{3}{|c|}{$\begin{array}{l}\text { Available potash in soil } \\
\text { (kg/ha) }\end{array}$} \\
\hline & 2017 & 2018 & Pooled & 2017 & 2018 & Pooled & 2017 & 2018 & Pooled & 2017 & 2018 & Pooled & 2017 & 2018 & Pooled \\
\hline $\mathbf{T}_{1}$ & 7.50 & 7.15 & 722 & .00 & 5.77 & 589 & 312 & 3.06 & & 6.65 & 4.14 & & 30.35 & 80.24 & \\
\hline $\mathbf{T}_{2}$ & -5 & 7.50 & & & & & & & & & & & & & \\
\hline $\mathbf{T}_{3}$ & .00 & 8.15 & 8.0 & 6.82 & 6.38 & 6.60 & 98.99 & 5 & 2 & 26.21 & & 3 & 28 & 74 & \\
\hline $\mathbf{T}_{4}$ & 00 & 6. & & 5.86 & 6. & & & & & & & & & & \\
\hline $\mathbf{T}_{5}$ & 7.70 & 8.00 & 7.85 & 6.20 & 6.40 & 6.30 & 212.14 & 205.50 & 208.82 & 27.41 & 24.56 & 25.99 & 271.12 & 268.05 & 269.59 \\
\hline$T_{6}$ & 6.80 & 6.95 & 6.88 & 6.43 & 5.85 & 6.14 & 231.50 & 198.56 & 21 & 23.67 & 23.47 & 23.57 & 268.46 & 259.11 & 263.79 \\
\hline $\mathbf{T}_{7}$ & 7.80 & 8.05 & 7.93 & 6.05 & 6.32 & 6.19 & 208.82 & 210.48 & 209.65 & 24.40 & 20.06 & 22.23 & 260.42 & 255.68 & 58.05 \\
\hline $\mathbf{T}_{8}$ & 7.50 & 7.85 & 7.68 & 6.34 & 6.16 & 6.25 & 216.33 & 204.65 & 210.49 & 25.12 & 21.71 & 23.42 & 266.34 & 258.55 & 262.45 \\
\hline SEm: & 0.17 & 0.16 & 0.12 & 0.21 & 0.18 & & & & & 0.79 & & & 8.45 & 8.23 & \\
\hline CD 5\% & 0.49 & 0.48 & 0.35 & 0.62 & 0.55 & 0.43 & 19.44 & 18.51 & 14.27 & 2.30 & 2.00 & 1.57 & NS & NS & 17.78 \\
\hline
\end{tabular}


Application of 100 per cent vermicompost + biofertilizers had positive effect on maximum number of branches per plant pooled (8.69) in tomato as compared to minimum number of branches (6.34) per plant in treatment $\mathrm{T}_{8} 75$ per cent organic +25 per cent inorganic fertilizers. Higher number of branches per plant in tomato might be due to reduced apical dominance, cell elongation and rapid cell division in growing portion may generate higher number of branches. Similar findings were also reported by Kumar et al., (2010), Gajbhiye et al., (2010) and Patil et al., (2009) in tomato.

Stem diameter and leaf area are significantly influenced by different organic and inorganic fertilizers, maximum stem diameter $(1.46 \mathrm{~cm})$ pooled and leaf area $\left(89.24 \mathrm{~cm}^{2}\right)$ pooled were recorded with treatment $\mathrm{T}_{2}$ (100 per cent RDF + biofertilizers).

This is might be due to the fact that the combined application of inorganic fertilizers along with biofertilizers associated with high photosynthetic activity and vigorous vegetative growth as reported by Prativa and Bhattarai (2011) and Singh et al., (2015) in tomato. Maximum number of clusters per plant (8.08) and number of fruits per cluster (6.60) were observed with the application of 100 per cent vermicompost along with biofertilizers.

These results indicates that biofertilizers is much pronounced when they are combined with organic manures. Organic manures not only balance the nutrient supply but also improve the soil physical and chemical properties. Similar trends were also observed by Kumar et al., (2010), Prativa and Bhattarai (2011) and Meena et al., (2014) in tomato.

\section{Soil nutrient status}

The results of soil nutrient analysis (Table 1 and 3 ) revealed that available $\mathrm{N}, \mathrm{P}$ and $\mathrm{K}$ content of soil were influenced by various applications of organic and inorganic fertilizers. Maximum available nitrogen $(237.15 \mathrm{~kg} / \mathrm{ha})$ pooled basis after completion of experiment (Table 3) in tomato was recorded with treatment $T_{1}$ (100 per cent RDF alone), maximum available phosphorus content $(25.99 \mathrm{~kg} / \mathrm{ha})$ was recorded with $\mathrm{T}_{5}$ (100 per cent organic management) closely followed by $(25.40 \mathrm{~kg} / \mathrm{ha})$ in treatment $\mathrm{T}_{1}(100$ per cent RDF alone). and maximum available potash content $(290.65 \mathrm{~kg} / \mathrm{ha})$ was recorded in treatment $\mathrm{T}_{2} \quad(100$ per cent $\mathrm{RDF}+$ Biofertilizers), whereas minimum available nitrogen $(197.82 \mathrm{~kg} / \mathrm{ha})$ was recorded with the application of 100 per cent vermicompost + biofertilizers, minimum available phosphorus content $(22.23 \mathrm{~kg} / \mathrm{ha})$ was recorded with treatment $\mathrm{T}_{7}(50$ per cent organic +50 per cent inorganic fertilizers) and minimum available potash content $(258.05 \mathrm{~kg} / \mathrm{ha})$ recorded with treatment $\mathrm{T}_{7}(50$ per cent organic +50 per cent inorganic fertilizers) in tomato. Integrated nutrient management failed to significant influence in available potassium content in soil after harvesting of tomato.

Higher amount of available NPK in soil with chemically treated plots as compared to combined application or organic manures might be due to poor soil physical structure and lack of microbial activity thus resulting in poor utilization of NPK as such treatments left over higher residual of these nutrients. Similar observation was reported by Chatterjee and Bandyopadhyay (2014), Prativa and Bhattarai (2011) in tomato and Tuti et al., (2014) in pepper under naturally ventilated polyhouse condition.

On the basis of present study, it may be concluded that the combined application of organic manures and inorganic fertilizers resulted in better growth and macro nutrient uptake from soil as compared to individual application of organic manures and inorganic fertilizers. 


\section{References}

Ahamd, M., Zeshan, S.H., Nasim, M., Zahir, Z.A., Nadeem, S.M., Nazli, F. and Jamil, M. 2015. Improving the productivity of cucumber through combined application of organic fertilizers and Pseudomonas fluorescens. Pakistan Journal of Agriculture Sciences, 52(4): 1011-1016.

Bairwa, H.L., Mahawer, L.N., Shukla, A.K., Kaushik, R.A. and Mathur, S.R. 2009. Response of integrated nutreint management on growth, yield and quality of okra (Abelmoschus esculentus). Indian Journal of Agricultural Sciences, 79(5): 381-384.

Chatterjee, R. and Badyopadhyay, S. 2014. Studies on effect of organic, inorganic and bio fertilizers on plant nutrient status and availability of major nutrients in tomato. International Journal of Bio-resource and Stress Management, 5(1): 93-97.

Dixit, P.S., Prasad, V.M., Kasera, S. and Singh, S. 2018. Effect of various inputs on growth and its attributes of tomato (Solanum lycopersicon L.) cv. GS-600 under polyhouse condition. International Journal of Chemical Studies, 6(6): 2537-2539.

Gajbhiye, R.P., Sharma, R.R. and Tewari, R.N. 2010. Effect of biofertilizers on growth and yield parameters of tomato. Indian Journal of Horticulture, 60(4): 368-371.

Kumar, H., Kaushik, R.A., Ameta, K.D., Regar, A.L., Rajawat, K.S. and Kumari, P. 2017. Effect of humic acid and nutrient mixture on quality parameter of tomato (Lycopersicon esculentum Mill.) under polyhouse condition. Journal of Applied and Natural Science, 9(3): 1369-1372.

Laxmi, R.P., Saravanan, S. and Naik, M.L. 2015. Effect of organic and inorganic fertilizers on plant growth, yield, fruit quality and shelf-life of tomato (Solanum lycopersicon L.) cv.
PKM-1. International Journal of Agriculture Science and Research, 5(2): 7-12.

Meena, R.K., Kumar, S., Maji, S., Kumar, D. and Kumar, M. 2014. Effect of organic manures and biofertilizers on growth, flowering, yield of tomato cv. Pusa Sheetal, International Journal of Agricultural Sciences, 10(1): 329332.

Olsen, S.R., Cole, C.S. Watanable, F.S. and Dean, C.A. 1954. Estiamtion of available phosphorus in soil by extraction with $\mathrm{NaHCO}_{3}$. USDA, Washington, DC., Circular, PP. 939.

Patil, D., Bhalekar, M.N., Bhagat, A.A. and Bhoge, R.S. 2009. Effect of organic manures and biofertilizers on growth and yield of tomato. Bioinfolet, 6(4): 338-339.

Piper, C.S. 1950. Soil and plant analysis. Inter Service Publishers, New York.

Prativa, K.C. and Bhattarai, B.P. 2011. Effect of integrated nutrient management on the growth, yield and soil nutrient status in tomato. Nepal Journal of Sciences and Technology, 12(2011): 23-28.

Singh, A., Jain, P.K., Sharma, H.L. and Singh, Y. 2015. Effect of planting date and integrated nutrient management on the production potential of tomato (Solanum lycopersicon Mill.) under polyhouse condition. Journal of Crop and Weed, 11(sp): 28-33.

Subbiah, B.V. and Asija, G.L. 1956. Alkaline method for determination of mineralizable nitrogen. Current Science, 25: 259-260.

Tuti, M.D., Hedau, N.K., Bisht, J.K and Bhatt, J.C. 2014. Effect of organic and inorganic sources of nutrient on yield, economics and energetic of pepper and soil properties in naturally ventilated polyhouse. Archives of Agronomy and Soil Science, 60(7): 1005-1014.

Walkley, A. and Black, I.A. 1947. Rapid titration method for organic carbon of soils. Soil Science, 37: 29-32.

\section{How to cite this article:}

Rajawat, K. S., K. D. Ameta, R. A. Kaushik, R. B. Dubey, H. K. Jain, Devendara Jain and Kaushik, M. K. 2019. Effect of Integrated Nutrient Management on Growth Attributes and Soil Nutrient Status of Tomato under Naturally Ventilated Polyhouse. Int.J.Curr.Microbiol.App.Sci. 8(10): 512-517. doi: https://doi.org/10.20546/ijcmas.2019.810.056 